\title{
The Value of Harmful Algal Bloom Predictions to the Nearshore Commercial Shellfish Fishery in the Gulf of Maine
}

\author{
Di Jin and Porter Hoagland* \\ Marine Policy Center \\ Woods Hole Oceanographic Institution \\ Woods Hole, Massachusetts 02543
}

May 1, 2008

*Corresponding author. Tel.:+1-508-289-2867; fax: +1-508-457-2184. E-mail address: phoagland@whoi.edu (P. Hoagland).

Acknowledgements: We would like to thank Andy Solow, Don Anderson, Dennis McGillicuddy, and Rick Stumpf for valuable observations and beneficial discussions and Mary Schumacher for editorial comments. The usual disclaimers apply. This paper is a result of research funded in part by the National Oceanic and Atmospheric Administration's Coastal Ocean Program under award \#NA04NOS4780270 to the Woods Hole Oceanographic Institution. ECOHAB Contribution No. 270 


\title{
The Value of Harmful Algal Bloom Predictions to the Nearshore Commercial Shellfish Fishery in the Gulf of Maine
}

\begin{abstract}
In this study, we develop a framework for measuring the value of harmful algal bloom (HAB) predictions. The framework captures the effects of both private and public responses to HABs. Using data from the New England nearshore commercial shellfish fishery and impact estimates for a large-scale HAB event in 2005, we illustrate how the potential value of HAB forecasts may be estimated. The results of our study suggest that the long-term value of a HAB prediction and tracking system for the Gulf of Maine is sensitive to the frequency of HAB events, the accuracy of predictions, the choice of HAB impact measures, and the effectiveness of public and private responses.
\end{abstract}

Keywords harmful algal bloom (HAB), red tide, fisheries, value of information, forecast, marine scientific research 


\section{Introduction}

During the last several decades, harmful algal bloom (HAB) events have been observed in more locations than ever before throughout the United States. Virtually all coastal regions of the United States are regarded now as potentially subject to a wide variety and increased frequency of HABs (Hoagland et al. 2002). The idea that harmful algal blooms (HABs) can result in serious economic impacts for a range of coastal businesses and users of the ocean is widely accepted by policymakers, natural resource managers, research scientists, industry officials, the media, and the public.

Public officials have a deep interest in developing a capacity for predicting HAB events. Prediction can be based on process-based or empirical models linking the occurrence of HAB events to observable environmental factors. Coupled bio-physical models useful for predicting blooms are under development for the Gulf of Maine, the Gulf of Mexico, and the Pacific Northwest. In congressional testimony delivered in 2003, Dr. Donald Scavia, former Senior Scientist at NOAA’s National Ocean Service, describes scientific research in this area:

In our laboratories and through the [ECOHAB] program, NOAA and our partners have investigated factors that regulate the dynamics of HABs and the mechanisms by which they cause harm. We have produced coupled bio-physical models that form a critical base for building HAB forecasts; applied technology from remote sensing, and medical science, to the detection and tracking of algal species and their toxins to help states target their monitoring and management efforts; and developed a national database where research findings are shared and made available to scientists and the public (Scavia 2003).

From a management perspective, it is crucial to begin developing an understanding of the scale of the economic costs to society of $\mathrm{HAB}$ events and to determine the extent to which predictive models might be useful in reducing these impacts. The scale of economic losses and the value of HAB predictions can tell us something about the appropriate scale of public and private investments in preventing or mitigating the losses. ${ }^{1}$

The objective of this study is to develop and apply a framework for assessing the economic value of the prediction of HAB events. The economic value of the prediction

\footnotetext{
${ }^{1}$ For example, Stel and Mannix (1996) describe two examples in which the accurate forecast of a HAB event may lead to significant reductions in related damages. In the case of offshore salmon farms, farmers could tow their enclosures to sites predicted to be safe from the bloom. In another case, operators of landbased fish farms using seawater could shut down pumps and wait for as long as a week for the peak of a bloom (in the typical case) to pass.
} 
of a HAB event arises from the use of the prediction in public and private decisionmaking. There is a well-established general formalism for assessing the value of information such as a prediction in economic decision-making. We develop this formalism for the problem of HAB prediction and apply it to nearshore commercial shellfisheries in the Gulf of Maine. We focus on blooms of algae (Alexandrium spp.) that produce paralytic shellfish poisoning (PSP). These blooms frequently result in the closure of productive shellfish beds along the coasts of Maine and Massachusetts, resulting in significant economic impacts (Shumway et al.1988; Jin et al. 2008). By developing a model for assessing the value of $\mathrm{HAB}$ predictions that can be adapted and applied generally, the study provides a potentially useful framework for investment decisions in scientific research and environmental monitoring to support $\mathrm{HAB}$ predictions.

The numerical example we present here illustrates a procedure for calculating the value of HAB prediction. Note, however, that the results presented here may not capture the full social value of a HAB prediction and tracking system. As discussed below, our choice of a HAB impact measure is based on an subset of fisheries, nearshore shellfish digging and growing. Further, our estimate reflects only the impacts arising from a largescale HAB event; it does not include the effects of more frequently occurring small-scale HAB events. Moreover, we consider only one of the potential private response options identified by fishermen (i.e., increasing harvests during the spring in advance of the large-scale event), and we do not consider other potential response options by individuals or firms in other sectors of the coastal economy. ${ }^{2}$ Finally, our analysis does not consider the potential benefits associated with the reopening of certain offshore shellfish fisheries on Georges Bank and in the Gulf of Maine, which arguably might occur once a HAB prediction system is in operation.

The remainder of this paper is organized as follows. Section 2 presents background information on HAB impact assessment, HAB prediction, and private and public decisions with respect to HAB events. Section 3 describes the methods for estimating the value of HAB prediction. Model specification and data are described in Section 4. The results of model estimations are summarized in Section 5. Section 6 presents our conclusions.

\footnotetext{
${ }^{2}$ The benefits of a HAB forecasting system in other sectors comprise enhanced capabilities to plan for alternative occupations and activities. For example, with advance notice of a bloom event, coastal tourists who engage in recreational shellfishing might choose to travel to a destination that is unaffected by a HAB closure.
} 


\section{Background}

\subsection{Economic Impact of the $2005 \mathrm{HAB}$}

Alexandrium fundyense is a dinoflagellate that produces a toxin that may be concentrated in the tissues of shellfish as they filter seawater for food. The toxin may cause paralytic shellfish poisoning (PSP) in humans that eat the shellfish. Current management measures include toxicity testing of shellfish throughout the coastal region, and closures of shellfish beds when a toxicity threshold ${ }^{3}$ is exceeded (Vakalopoulos et al. 2006).

The 2005 bloom of Alexandrium fundyense was the most widespread and intense in New England waters since a similar event more than three decades earlier. In 2005, record levels of PSP toxicity were measured at some locations where PSP had been known to occur, while at other locations PSP toxicity was measured for the first time ever. Record-level concentrations of algal cells were observed in the southwestern Gulf of Maine. Other records set in 2005 include the earliest toxicity, the longest closures, and the largest area affected (i.e., a large closure of federal waters). Disaster declarations were issued in Maine and Massachusetts, as shellfishermen were unable to harvest from the affected areas for prolonged periods. The shellfish closures along the New England coast were instituted in April and August ${ }^{4}$ with the most significant closures occurring from May to July.

Using historical data from the National Marine Fisheries Service, the Massachusetts Division of Marine Fisheries, and other sources, we developed estimates of the direct economic impacts of the 2005 event on the nearshore commercial shellfish fisheries in Maine and Massachusetts (Jin et al. 2008). Our measure of HAB impact is based on a comparison of two scenarios: with and without the HAB event. Specifically, we examined changes in the value of nearshore shellfish landings:

$$
\Delta V=V_{A}-V_{B}
$$

\footnotetext{
${ }^{3}$ A toxicity threshold is the level at which humans are deemed by experts to be adequately protected from illness or death.

${ }^{4}$ Massachusetts Division of Marine Fisheries records on shellfish area closures and openings cover a period from April 27 - August 19, 2005.
} 
where $A$ and $B$ refer to the two scenarios with- and without-HABs; $V_{A}$ represents the actual harvest value in 2005 and $V_{B}$ is a baseline harvest value. ${ }^{5}$ The results indicate that the total direct impacts in Maine were \$2.5 million, including lost revenues in the softshell clam and mussel fisheries. The total direct impacts on the nearshore commercial shellfish industry in Massachusetts were \$15.7 million (see Table 1).

\subsection{Development of Predictive Models}

Scientists have called for methods and technologies to mitigate the adverse impacts of blooms (e.g., NSGCP 2001; CENR 2000; HAMM 1999; Boesch et al. 1997; Anderson 1995; Anderson et al. 1993). A set of important management tools that are being developed involve the use of monitoring technologies and predictive models that would allow for the possibility of forecasting bloom events of the toxic dinoflagellate Alexandrium fundyense in the Gulf of Maine and initiating private or public responses to minimize economic impacts (e.g., Anderson et al. 2000, 2005; McGillicuddy et al. 2003).

Alexandrium has historically bloomed in the Bay of Fundy, but blooms were not known to occur in the southwestern Gulf of Maine, including Massachusetts Bay, until 1972, when a slow-moving hurricane brought cells down the coast, presumably from the Bay of Fundy. Following the 1972 bloom, recurrent annual outbreaks have been observed in northern Massachusetts, New Hampshire, and western Maine. Further south, in Massachusetts Bay, shellfish toxicity was frequently observed from 1972 to 1993 but was nearly absent from 1994 to 2004 (Anderson et al. 2005; Vakalopoulos et al. 2006). The extensive bloom in 2005 was the result of favorable offshore circulation, wind, and river runoff, including two or more "northeaster" storms that pushed waters onshore. In addition, cysts were abundant in offshore sediments (Vakalopoulos et al. 2006).

Researchers at WHOI have developed a hindcast model that is capable of simulating the large-scale structure of the 2005 bloom in its initiation and development phases (from March to June). The model has been improved to simulate bloom termination as well. The coupled physical/biological modeling system covers the Gulf of Maine, Massachusetts Bay, and waters south of Cape Cod, with a spatial resolution on the order of $1 \mathrm{~km}$ along the coast and growing to roughly $30 \mathrm{~km}$ in deeper waters (He et al. 2005; Vakalopoulos et al. 2006).

\footnotetext{
${ }^{5}$ We examine gross values (price times quantity of fish landed). We do not examine net values because of the lack of data on fishing costs in the shellfish sector. Note that, if costs are close to revenues, there would be little welfare impact.
} 
The model runs rely on a substantial amount of field data and constant updating of these data inputs. The data include the speeds and directions of ocean currents, water temperature and salinity, winds, surface heat exchanges, tides, river runoff, the distribution and behavior of Alexandrium cells in the water and in seafloor sediments, waterborne nutrients, solar radiation, and large-scale motions in the North Atlantic Ocean. While current weather and oceanographic data are readily available at present, it is time consuming and costly to collect field data on cyst abundance and nutrient levels. Without real-time and in-situ data on cells and nutrients, researchers must substitute the long-term means of relevant parameters, which in turn affect the precision of the model results.

With sufficient technical and financial support, the model system should be able to generate red tide forecasts, a few weeks in advance, on a regular basis. Given that the red tide model uses weather predictions (e.g., wind) as inputs, one may view the precision of weather forecasts as an upper limit for the precision of the red tide forecast.

\subsection{Private Decision-making in Response to HAB Prediction}

Shellfish growers and shellfishermen alike are concerned with both the timing and duration of HAB closures. Growers tend to be involved in business planning to a more significant extent than shellfishermen. Therefore, growers are more likely to take advantage of HAB predictions than shellfishermen. At present, however, supplies from aquaculture account for only a small fraction of the total nearshore shellfish production in Maine and Massachusetts.

The ability to plan for a closure in advance of the event can make a difference. Unexpected closures are costly to both growers and shellfishermen. At this time, most growers see little value in long-term annual predictions of HAB events, however, although they do see some value in one- to two-week forecasts of potential closures. Given a short-term forecast, their primary strategy would be to harvest product in advance of a closure. Because the main market is for fresh product, with a pending closure, shellfish can be harvested in advance of a bloom and kept alive for a short period of time to be sold as needed. Given a forecast of a closure, most shellfishermen also are likely to try to harvest as much product as they can prior to the closure. This strategy is limited by the time of year (availability of markets), tides, and legal restrictions. In the case of a major bloom, like the 2005 event, these response measures, which are relatively 
small in scale, are unlikely to mitigate all of the negative impact of HABs on the shellfishing industry.

\subsection{Public Decision-making in Response to HAB Prediction}

In both Maine and Massachusetts, the existing monitoring system for HABs involves an ongoing program of sampling and performing tests to determine the level of toxicity (typically by conducting numerous mouse bioassays). In the event that toxic levels of shellfish poison are discovered in sampled shellfish, by law, a portion of the intertidal and submerged lands must be closed to shellfishing until subsequent tests show that the HAB has dissipated. The closures relate exclusively to the protection of public health; there is no explicit consideration of the costs of closures to either commercial or recreational shellfishermen or aquaculturists. This practice could be justified on economic grounds, since public health costs associated with seafood poisoning resulting from non-closure would likely be much greater than the losses from shellfishing.

Monitoring in Maine takes place from April to October. Each year, between 4,000 and 5,000 mouse bioassays are performed. Maine spends approximately $\$ 280,000$ on its monitoring and management program for HABs each year.

Because HAB prediction models can track a HAB event spatially and temporally, state shellfish managers can utilize model information to guide their management actions. Specifically, rather than cordoning off large areas, they may be able to close fishing areas more selectively and precisely. Thus, during a HAB year, a larger number of unaffected shellfish beds may be kept open, thereby minimizing lost landings.

\section{Methods}

A well-established model exists for assessing the economic value of predictions of future conditions. This model has been applied to assess the value of long-range climate prediction, including ENSO prediction, to US agriculture (Adams et al. 1995; Kite-Powell and Solow 1994; Solow et al. 1998) and to the salmon fishery in the Pacific Northwest (Costello et al. 2001; Costello et al. 1998). Using this approach, the value of $\mathrm{HAB}$ predictions to a shellfishery is given by the expected difference between the economic value that results when the prediction is used in decision-making and the economic value that results when the prediction is not used in decision-making.

The model for assessing the value of prediction is as follows (for fuller 
treatments, see Berger [1985] or Clemen [1996]). Let $\alpha$ denote a particular action undertaken by a decision-maker and let the random variable $S$ denote the true state of nature. Suppose that the state of nature concerns the occurrence or non-occurrence of a HAB event within a year. Thus, $S$ can take one of two values: $H$ (a HAB event occurs) or $N$ (an event does not occur). Finally, let $V(\alpha \mid H)$ be the annual economic value to the decision-maker for action $\alpha$ when a HAB event occurs, and, similarly, let $V(\alpha \mid N)$ be the annual value for action $\alpha$ when an event does not occur. In the absence of a prediction of $S$, the expected benefit $\left(V_{0}\right)$ for action $\alpha$ is given by:

$$
E\left[V_{0}(\alpha)\right]=V_{0}(\alpha \mid H) \operatorname{prob}(H)+V_{0}(\alpha \mid N) \operatorname{prob}(N)
$$

Let $\pi$ be the probability of a HAB event, and (1) becomes:

$$
E\left[V_{0}(\alpha)\right]=V_{0}(\alpha \mid H) \pi+V_{0}(\alpha \mid N)(1-\pi)
$$

Suppose $\alpha=\{H, N\}$, that is, the decision-maker can take one of two actions: $H$ (an alternative harvest schedule in response to $\mathrm{HAB}$ ) or $N$ (normal harvest schedule for noHAB years). The optimal action $\alpha^{*}(=H$ or $N$ ) is the one for which the expected benefit (2) is maximized.

$$
\alpha^{*}=\arg \max _{\alpha}\left\{E\left[V_{0}(H)\right], E\left[V_{0}(N)\right]\right\}
$$

Note that, in the absence of a prediction, the event probability $\pi$ remains constant from year to year. As a result, other things being equal, the optimal action $\alpha^{*}$ also remains constant from year to year.

Suppose now that an annual prediction of $S$ is issued prior to the decision point. Let the random variable $X$ denote this prediction, which can also take only two values: $H$ or $N$. Let $x$ be the prediction in a particular year. In light of this prediction, the decisionmaker updates the probability of $H$ or $N$ according to Bayes's Theorem:

$$
\operatorname{prob}(s \mid x)=\frac{\operatorname{prob}(x \mid s) \operatorname{prob}(s)}{\operatorname{prob}(x)}
$$

where $\operatorname{prob}(s \mid x)$ is the posterior probability. $\operatorname{prob}(x \mid s)$ is the likelihood function of $x$, given $s$, that is, the likelihood that prediction $x$ will have been made, given that the true state of nature is $s . \operatorname{prob}(s)$ is the prior probability reflecting the decision-maker's existing knowledge about $S$. In our case $S=\{H, N\}$, the posterior probabilities are:

$$
\operatorname{prob}(H \mid x)=\frac{\operatorname{prob}(x \mid H) \pi}{\operatorname{prob}(x)} \text { and } \operatorname{prob}(N \mid x)=\frac{\operatorname{prob}(x \mid N)(1-\pi)}{\operatorname{prob}(x)}
$$


and

$$
\operatorname{prob}(x)=\sum \operatorname{prob}(x \mid s) \operatorname{prob}(s)=\operatorname{prob}(x \mid H) \pi+\operatorname{prob}(x \mid N)(1-\pi)
$$

is the probability of predicting $x(=H$ or $N)$. The likelihood function is a measure of prediction skill. For example, for a perfect prediction, $\operatorname{prob}(x \mid s)=1$ if $x=s$ and 0 otherwise for both $s=H$ and $s=N$. In contrast, for a completely non-informative prediction, $\operatorname{prob}(x \mid s)=1 / 2$ irrespective of $x$ and $s$. Once the decision-maker updates the probabilities, he acts as before to choose the optimal action $\alpha^{* *}(x)$ to maximize expected benefits $\left(V_{1}\right)$ :

$$
E\left[V_{1}(\alpha \mid x)\right]=V_{1}(\alpha \mid H) \operatorname{prob}(H \mid x)+V_{1}(\alpha \mid N)(1-\operatorname{prob}(H \mid x))
$$

That is,

$$
\alpha^{* *}(x)=\arg \max _{\alpha(x)}\left\{E\left[V_{1}(H \mid x)\right], E\left[V_{1}(N \mid x)\right]\right\}
$$

Note that $V_{l}$ is the value function with a HAB prediction, which may differ from the value function without a prediction $\left(V_{0}\right)$. This is because the HAB forecast system is capable of tracking $\mathrm{HAB}$ movement, which leads to a reduction in the total area closed for $\mathrm{HAB}$ and, in turn, a reduction in economic losses.

For the decision-maker, the difference in expected benefits when the prediction is $x$ is:

$$
D(x)=E\left\{V_{1}\left[\alpha^{* *}(x)\right]\right\}-E\left[V_{0}\left(\alpha^{*}\right)\right]
$$

Note that this difference is conditional on the prediction being $x$. For $X=\{H, N\}$, the unconditional difference is given by:

$$
D=D(H) \operatorname{prob}(X=H)+D(N)(1-\operatorname{prob}(X=H))
$$

The quantity $D$, which can be shown to be non-negative, is the annual value of prediction to the decision-maker. For a period of $T$ years $(t=1, \ldots, T)$, the net present value (NPV) of forecasting is:

$$
\sum_{t=1}^{T} \frac{D}{(1+\delta)^{t}}
$$


It is important to point out that the value of prediction to a region, as opposed to an individual decision-maker, will be the product of decisions made by many decisionmakers. In the case of HAB predictions for a commercial shellfishery, these decisionmakers will include both private harvesters and shellfish managers. We develop estimates of the aggregated value at the regional level using results from models of a regional shellfish fishery under different management scenarios.

In summary, estimating the value of HAB forecasting in the New England nearshore shellfishery involves four steps. The first step is to measure the economic impacts (e.g., harvest losses) of HAB events in the absence of prediction. Essentially, this involves an economic impact analysis of the status quo. The second step is to characterize the prediction itself. We focus on the situation in which the goal of HAB prediction is to predict the occurrence or non-occurrence of a large-scale event within a year. The value of HAB prediction depends on the accuracy or skill of the prediction. We assess the value for a range of potential skill levels. The third step in the assessment of the value of HAB prediction is to examine how decisions would be made in light of a HAB prediction. This step involves identifying a range of potential responses by public and private decision-makers and evaluating their economic consequences. The last step involves developing an overall measure of prediction value using the model described in the previous section.

\section{Model Specification and Data}

To estimate the value of HAB forecasting, we need to define the value function $(V)$ for different actions $(\alpha)$ under different states of nature $(s)$ without prediction (eq. 2$)$ and with prediction (eq. 7). In our framework, $\alpha=\{H, N\}$ and $S=\{H, N\}$, so we have four annual values each for $V_{0}$ and $V_{l}$. The $V$ function captures the aggregate value at the industry level. In the nearshore shellfish industry, the relevant decision-maker could be either a shellfisherman or an aquaculturist (we refer to both types of decision-makers as "fishermen" here). A fisherman would maximize the net revenue of his business by choosing optimal levels of factor inputs (i.e., fishing effort). Generally, in the absence of a HAB prediction, the fisherman makes his decision according to experience (eq. 3). He may make a different decision, however, on the basis of a HAB prediction (eq. 8). Assuming that fishermen act similarly with respect to HAB events, ${ }^{\mathbf{6}}$ we consider the sum

\footnotetext{
6 The assumption of uniform behavior is, of course, a strong one. Fishermen might respond to information in different ways, depending upon the set of available opportunities, risk profiles, endowments, among other
} 
of revenues across individual fisherman; in other words, we assume that there is a decision-maker for the industry. We do not examine changes in fishing effort or associated costs explicitly, because of a lack of relevant data.

In addition, we assume that HAB prediction capability will not replace existing monitoring and that the predictions need in situ validation to ensure public health safety. Thus, we assume that HAB prediction will not significantly reduce the level of field testing and associated costs.

As shown in Table 2 and Figure 1, there is a seasonal trend in nearshore shellfish landings in Maine. To estimate the value of HAB predictions, we use the baseline value (i.e., the 2000-2004 average) for non-HAB years and the 2005 value for HAB years. ${ }^{7}$ We do not have monthly statistics for Massachusetts and therefore assume that the time profile for Maine is applicable to Massachusetts. ${ }^{8}$ We divide a year into three periods: Period I (January through March), Period II (April through August), and Period III (September through December). In a HAB year, the three periods correspond to the preHAB phase, the HAB phase, and the post-HAB phase, respectively. ${ }^{9}$

The benefits associated with HAB prediction consist of two parts. The first part is related to private decisions made by fishermen in Period I. Specifically, fishermen have two options in their decision set: to increase harvest level in March $(\alpha=H)$ or to maintain a baseline harvest level in March $(\alpha=N)$. In a HAB year, increased harvest in the preHAB phase will partially offset losses in the HAB phase. However, in a non-HAB year, the increased harvest in March is suboptimal and results in a reduction in the total revenue in that year. The second part of the benefit may be realized when shellfish managers in Period II in a HAB year decide to close fishing areas more selectively than they otherwise would, based on information from the HAB tracking model. The improvement in public decision-making about closures effectively makes the scale of a HAB “smaller," and thus the HAB-related losses are reduced. We capture this effect by specifying the value functions without and with prediction ( $V_{0}$ and $\left.V_{l}\right)$ differently.

For Period III, we assume that harvests are the same for both HAB and non-HAB years (Figure 1). Direct economic losses to nearshore shellfish harvesters result from the

conditions. If only a subset of fishermen rely upon HAB predictions, our assumption would overestimate the value of prediction.

${ }^{7}$ A small adjustment was made to the time profile of 2005 landings during the HAB months to smooth the curve.

${ }^{8}$ For a detailed description of shellfish landings data in the two states and the 2005 HAB impacts, see Jin et al. (2008).

${ }^{9}$ In reality, the lengths of each phase may vary, i.e., the HAB period may be longer or shorter. 
coincidence of timing between environmental conditions ripe for a HAB and market demand, which typically peaks during the spring and summer tourist season. The primary product form is a live product sold in a market with a distinct seasonal demand. Thus, although PSP does not kill shellfish, sales losses due to a PSP event in the spring or summer cannot be offset by increasing harvest later in the year because of a much lower demand then for live shellfish.

We specify six model scenarios to estimate the value of HAB prediction under different conditions (Table 3). In Models A through C, we examine the effects of the fishermen's response only. The combined effects of private and public decisions are simulated in Models D through $\mathrm{F}$. We estimate the values for $V_{0}$ and $V_{l}$ in Table 4 as follows. Each year fishermen decide either to take HAB response actions (to increase harvest levels in March) or not (to follow a regular harvest schedule), and, in Period II, a HAB either occurs or does not occur.

For a non-HAB year, when fishermen do not take response actions $(\alpha=N ; s=N)$, both $V_{0}(N \mid N)$ and $V_{1}(N \mid N)$ equal the annual value of nearshore shellfish landings in the baseline years. In the case of Maine, for example, nearshore shellfish landings total $\$ 20.9$ million. For a HAB year, when fishermen do not take response actions ( $\alpha=N$; $s=$ $H$ ), $V_{0}(N \mid H)$ equals the annual value in 2005 (\$18.5 million in Maine). Because of HAB tracking and improved public decisions, $V_{1}(N \mid H)$ may be larger than $V_{0}(N \mid H)$. For a $25 \%$ and $10 \%$ reductions in the area closed for $\mathrm{HAB}, V_{1}(N \mid H)$ equals $\$ 19.1$ million and \$18.7 million, respectively, for Maine.

For a non-HAB year, when fishermen take response actions ( $\alpha=H ; s=N)$, we assume that both $V_{0}(H \mid N)$ and $V_{1}(H \mid N)$ is 5\% lower than the baseline value (\$19.9 million in Maine). Note that to increase harvest in March is non-optimal for a non-HAB year. Finally, for a HAB year, when fishermen take response actions ( $\alpha=H ; s=H$ ), ceteris paribus, $V_{i}(H \mid H)$ is greater than that in a HAB year when no actions are taken [ $V_{i}(N \mid H)$ with $i=0$ or 1$]$, because increased harvest in March partially offsets the losses in landings in Period II.

Since $V_{i}(H \mid H)$ captures the beneficial effects of HAB response actions, it is a key component in assessing the value of HAB predictions. As noted above, the strategy to increase harvest in March is limited by the availability of markets, tides, and legal restrictions. As shown in Table 3, we assume that fishermen may increase their March harvest value by $25 \%$ to $100 \%$. As noted, the red tide forecast capability should enable shellfish managers to design more precise and selective closures, so that the costs associated with lost landings may be minimized. We assume that the losses will be 
lowered by $10 \%$ to $25 \%$ each month during the HAB phase (April through August) (see Figure 1). Combining the effects of increased harvest in March and reduced losses in HAB months, we have our high-end and low-end estimates for $V_{1}(H \mid H)$, which are \$20.4 million and \$19.0 million, respectively, in Maine (see Models D and F in Table 4).

Major HAB events, such as the 2005 red tide, do not occur frequently in New England. For our estimation of the value of HAB prediction, we examine five frequency estimates: 2-, 5-, 10-, 20-, and 30- year events and associated prior probabilities $(\pi=0.5$, $0.2,0.1,0.05$, and 0.033 , respectively). The forecast system currently under development may provide predictions of varying degrees of accuracy. We examine three levels of accuracy: 100\%, 90\%, and 80\% (Table 5). Combining our prior and likelihood probabilities and using (5) and (6), we calculate the posterior distributions as presented in Table 6. Note that a useful prediction alters the prior probability for a HAB event to a different posterior probability. For example, when HAB is a 10 -year event, the prior $[\operatorname{prob}(s)=\pi]$ is 0.1 . If the prediction is $100 \%$ accurate, the posterior probability for a HAB event $(s=H)$ is 1.0 given a HAB prediction $(x=H)$. If the prediction is $90 \%$ accurate and a HAB is predicted, the posterior is 0.5 for $s=H$.

\section{Results}

Annual values of HAB predictions for Models A through $\mathrm{C}$ under different assumptions are calculated separately using (10), and the results are summarized in Table 7. These model scenarios simulate the fishermen's responses only and do not incorporate a public response. When the $\mathrm{HAB}$ is a 10 -year event, the prediction is $100 \%$ accurate, and fishermen can respond to a HAB prediction by doubling their March harvest level (Model A), the values of the prediction are \$127,000 and \$131,000 per year for Maine and Massachusetts, respectively. The total value from private response is $\$ 258,000$ annually. If the accuracy of prediction is reduced to $90 \%$, the total value of prediction is reduced to $\$ 41,000$ per year. Because fishermen’s response options are very limited and small in scale, the value of prediction is zero for an imperfect prediction in Models B and C (representing 50\% and 25\% increase in March harvest, respectively). Generally, the value of HAB prediction decreases when the HABs are less frequent and when the fishermen's response is more constrained. For example, if the HAB is a 30year event and the response scenario is as depicted in Model C, the total value of a HAB forecast system making perfect predictions is only $\$ 21,000$ per year. In contrast, if the $\mathrm{HAB}$ is a 2-year event, the total value associated with Model A is over $\$ 1$ million per year. 
Table 8 presents the value of the HAB forecast system resulting from public responses. Recall that shellfish managers can minimize closed areas during a HAB event using information from the HAB tracking model. Thus, $V_{1}(N \mid H)>V_{0}(N \mid H)$, that is, even without ex ante response in March, fishermen can harvest more shellfish during a HAB season because a smaller area is closed (i.e., a larger area is kept open). The total value of the tracking model is $\$ 455,000$ per year if the closed area is reduced by $25 \%$ and the HAB is a 10 -year event. The value is smaller if HABs are less frequent and the tracking is less effective, and vice versa.

We calculate the combined value of the HAB prediction model given both private and public responses using Models $\mathrm{D}$ through $\mathrm{F}$ and report the results in Table 9. The figures in the Table 9 are, in fact, the sums of those in Tables 7 and 8 . Assuming that $\mathrm{HAB}$ is a 10 -year event and the prediction is perfect, the total annual value is $\$ 713,000$ for highly effective responses (Model D). The total value is reduced to $\$ 61,000$ if the responses are not very effective (Model F), the HABs are less frequent, and the prediction is not perfect. In contrast, the total value increases to over \$3 million if the HABs are frequent (every other year) and the responses are effective (Model D). We compute the long-term value of $\mathrm{HAB}$ prediction using equation 11 and a $5 \%$ social discount rate. As illustrated in Table 10, the net present value (NPV) over 30 years ranges from $\$ 51.3$ million to \$0.9 million, depending on HAB frequency, accuracy of prediction, and responses.

\section{Conclusions}

HABs can lead to serious economic impacts in commercial shellfish fisheries. From a management perspective, it is crucial to understand the scale of the economic costs to society of HAB events and to determine the extent to which predictive models might be useful in reducing these impacts. The value of HAB prediction can tell us something about the appropriate scale of public investments in developing HAB forecasting and tracking systems.

We have developed a framework for measuring the value of HAB predictions. Our model captures the effects of both fishermen's and shellfish managers' HAB responses. Using data from the New England nearshore commercial shellfish fishery and impact estimates for the 2005 red tide event, we show how the value of HAB forecasting to the nearshore shellfish fisheries may be calculated. Results of our study suggest that the long term value of a HAB prediction and tracking system for the Gulf of Maine is 
quite sensitive to HAB frequency, accuracy of prediction, the initial choice of a HAB impact measure, and the effectiveness of public and private responses.

Although our model includes essential interactions in HAB management in the nearshore shellfish industry, it does not capture the full benefits associated with reliable HAB prediction. In addition to increasing harvest in March, several other private response options available to the fishermen may generate measurable benefits. For example, fishermen may switch to another geographic location or another activity, once a preferred location is closed; they may harvest and relay the shellfish to protected waters from which the shellfish can be harvested a second time before delivery to the market; or they may harvest and hold product as frozen inventories. Furthermore, our example ignores the potential benefits of a forecasting system to other fisheries, especially potential offshore shellfisheries such as Atlantic surf clam and ocean quahog, specialized markets, such as roe-on-scallop, and other sectors, including recreational fishing and coastal tourism. As estimates of economic impacts in these other sectors become more clear, the value of HAB predictions is likely to grow. An extension of the present study should include analyses of alternative response options, the benefits of predictions to other sectors of the economy, and a more refined treatment of the spatial and temporal aspects of $\mathrm{HAB}$ management. 


\section{References}

Adams, R.M., K.J. Bryant, B.A. McCarl, D.M. Legler, J. O'Brien, A.R. Solow and R.F. Weiher. 1995. Value of improved long-range weather information. Contemporary Economic Policy 13: 10-19.

Anderson, D.M. 1995. ECOHAB: the ecology and oceanography of harmful algal blooms. Woods Hole, Mass.: Department of Biology, Woods Hole Oceanographic Institution.

Anderson, D.M., S.B. Galloway and J.D. Joseph. 1993. Marine biotoxins and harmful algae; a national plan. WHOI Tech. Rept. 93-02. Woods Hole, Mass.: Department of Biology, Woods Hole Oceanographic Institution.

Anderson, D.M., B.A. Keafer, J.H. Churchill, R.P. Signell and W.R. Geyer. 2000. Alexandrium blooms in the western Gulf of Maine. Symp. On Harmful Algae in the United States. Woods Hole, Mass.: Marine Biological Laboratory (4-9 December).

Anderson, D.M., B.A. Keafer, D.J. McGillicuddy Jr., M.J. Mickelson, K.E. Keay, P.S. Libby, J.P. Manning, C.A. Mayo, D.K. Whittaker, J.M. Hickey, R. He, D.R. Lynch and K.W. Smith. 2005. Initial observations of the 2005 Alexandrium fundyense bloom in southern New England: general patterns and mechanisms. Deep-Sea Research II $52: 2856-2876$.

Berger, J.O. 1985. Statistical Decision Theory and Bayesian Analysis. New York: Springer-Verlag.

Boesch, D.F., D.M. Anderson, R.A. Horner, S.E. Shumway, P.A. Tester and T.E. Whitledge. 1997. Harmful algal blooms in coastal waters: options for prevention, control, and mitigation. Decision Analysis Series No. 10. Silver Spring, Md.: Coastal Ocean Program, US National Oceanic and Atmospheric Administration.

Clemen, R.T. 1996. Making Hard Decisions: An Introduction to Decision Analysis. Belmont, Calif.: Duxbury Press, Wadsworth Publishing Company.

Committee on Environment and Natural Resources (CENR). 2000. National assessment of harmful algal blooms in US waters. Washington: US National Science and Technology Council (October).

Costello, C., R. Adams and S. Polasky. 1998. The value of El Niño forecasts in the management of salmon: a stochastic dynamic assessment. American Journal of Agricultural Economics 80: 765-777.

Costello, C., S. Polasky and A.R. Solow. 2001. Renewable resource management with environmental prediction. Canadian Journal of Economics 34(1): 196-211.

Harmful Algae Management and Mitigation (HAMM). 1999. Conference summary. http://vm.cfsan.fda.gov/ frf/hamm99su.html. Subic Bay, Philippines (10-14 May).

He, R., D.J. McGillicuddy, D.R. Lynch, K.W. Smith, C.A. Stock and J.P. Manning. 2005. Data assimilative hindcast of the Gulf of Maine coastal circulation. Journal of Geophysical Research 110(C10011):1-20. 
Hoagland, P., D.M. Anderson, Y. Kaoru and A.W. White. 2002. The economic effects of harmful algal blooms in the United States: estimates, assessment issues, and information needs. Estuaries 25(4b):819-837.

Jin, D., E. Thunberg and P. Hoagland. 2008. Economic impact of the 2005 red tide event on commercial shellfish fisheries in New England. Ocean and Coastal Management 51(5):420-429.

Kite-Powell, H.L. and A.R. Solow. 1994. A Bayesian approach to estimating benefits of improved forecasts. Meteorological Applications 1: 351-354.

McGillicuddy Jr., D.J., R.P. Signell, C.A. Stock, B.A. Keafer, M.D. Keller, R.D. Hetland and D.E. Anderson. 2003. A mechanism for offshore initiation of harmful algal blooms in the coastal Gulf of Maine. Journal of Plankton Research 25(9):1131-1138.

National Sea Grant College Program (NSGCP). 2001. Prevention, control, and mitigation of harmful algal blooms: a research plan. Silver Spring, Md.: US National Oceanic and Atmospheric Administration.

Scavia, D. 2003. Testimony before the Subcommittee on Environment, Technology, and Standards, US House of Representatives. Washington: National Ocean Service, National Oceanic and Atmospheric Administration, US Department of Commerce (13 March). Found at: http://www.legislative.noaa.gov/Testimony/031303scavia.pdf [last accessed on 25 January 2004].

Shumway, S.E., S. Sherman-Caswell and J.W. Hurst. 1988. Paralytic shellfish poisoning in Maine: monitoring a monster. Journal of Shellfish Research 7(4): 643-652.

Solow, A.R., R.F. Adams, K.J. Bryant, D.M. Legler, J. O'Brien, B.A. McCarl, W. Nayda and R.F. Weiher. 1998. The value of ENSO forecasts: the case of US agriculture. Climatic Change 39: 47-60.

Stel, J.H. and B.F. Mannix. 1996. A benefit-cost analysis of a regional global ocean observing system: Seawatch Europe. Marine Policy 20(5):357-376.

Vakalopoulos, C.C., M.J. Mickelson and J. Pederson. 2006. Summary of Symposium on the Alexandrium fundyense Red Tide of 2005. MIT Sea Grant Report. MITSG 06-7, 9pp. Cambridge, MA. 
Table 1. Changes in Landings: Baseline versus 2005

\begin{tabular}{llrrr}
\hline \multicolumn{1}{c}{ State } & \multicolumn{1}{c}{ Species } & Baseline & 2005 & Change \\
\hline Maine & Softshell clam & $11,243,910$ & $9,163,229$ & $-2,080,681$ \\
& Mussel & $1,557,289$ & $1,165,544$ & $-391,745$ \\
\hline & & Sum & $-2,472,426$ \\
\hline \multirow{2}{*}{ Massachusetts } & Quahog & $7,818,398$ & $1,664,095$ & $-6,154,302$ \\
& Softshell clam & $11,850,575$ & $3,991,344$ & $-7,859,231$ \\
& Mussel & $1,888,350$ & 177,898 & $-1,710,452$ \\
\hline & & Sum & $-15,723,986$ \\
\hline
\end{tabular}

Notes:

All values are in 2005 dollars. Values in different years are converted to 2005 using PPI (Producer Price Index) for unprocessed shellfish.

For Maine, values are the sums of monthly landings from April to August; baselines are constructed by computing the 2000-2004 average values.

For Massachusetts, values are the annual totals; baselines are constructed by computing the 1990-2004 average values.

For details, see Tables 1, 3, and 4 and related discussions in Jin et al. (2008). 
Table 2. Value of Monthly Landings of Softshell Clams and Mussels in Maine

\begin{tabular}{lrrr}
\hline Month & Baseline & With HAB & Losses \\
\hline Jan & 900,757 & 900,757 & 0 \\
Feb & 944,352 & 944,352 & 0 \\
Mar & $1,269,741$ & $1,269,741$ & 0 \\
Apr & $1,454,168$ & $1,135,058$ & $-319,110$ \\
May & $2,001,316$ & $1,444,940$ & $-556,376$ \\
Jun & $2,761,211$ & $1,956,901$ & $-804,310$ \\
Jul & $3,128,955$ & $2,789,166$ & $-126,247$ \\
Aug & $3,455,549$ & $3,002,708$ & $-666,383$ \\
Sep & $1,691,273$ & $1,691,273$ & 0 \\
Oct & $1,330,727$ & $1,330,727$ & 0 \\
Nov & 956,475 & 956,475 & 0 \\
Dec & $1,054,161$ & $1,054,161$ & 0 \\
Sum & $20,948,685$ & $18,476,259$ & $2,472,426$ \\
\hline
\end{tabular}

Note:

Values are in 2005 dollars.

Baselines are constructed by computing the 2000-2004 average values.

Values with HAB (in 2005) are adjusted to exclude changes unrelated to the red tide during non-HAB months (January - March and September - December). 
Table 3. Model Scenarios

\begin{tabular}{ccc}
\hline Model & $\begin{array}{c}\text { Increased Harvest in } \\
\text { March (\%) }\end{array}$ & $\begin{array}{c}\text { Reduction in } \\
\text { Closed Area (\%) }\end{array}$ \\
\hline A & 100 & 0 \\
B & 50 & 0 \\
C & 25 & 0 \\
D & 100 & 25 \\
E & 50 & 25 \\
F & 25 & 10 \\
\hline
\end{tabular}

Notes:

Increased harvest in March is relative to the harvest level in the same month in regular (i.e., non-HAB) years.

Reduction in closed area is from a typical HAB closure without the ability to track HAB movement. 
Table 4. Annual Values of Shellfish Landings in Massachusetts and Maine

\begin{tabular}{|c|c|c|c|c|c|c|c|c|c|c|}
\hline Action $(\alpha)$ & $\begin{array}{l}\text { State of } \\
\text { Nature (s) }\end{array}$ & $\begin{array}{l}\text { Value } \\
\text { Function }\end{array}$ & $\begin{array}{l}\mathrm{M} \\
\mathrm{A}\end{array}$ & $\begin{array}{l}\text { ode } \\
\text { B }\end{array}$ & C & & E 1 & $\mathrm{~F}$ & Maine & Massachusetts \\
\hline $\mathrm{N}$ & $\mathrm{N}$ & $\mathrm{V}_{0}(\mathrm{~N} \mid \mathrm{N})$ & $\mathrm{x}$ & $\mathrm{X}$ & $\mathrm{x}$ & $\mathrm{x}$ & $\mathrm{x}^{2}$ & $\mathrm{x}$ & $20,948,685$ & $21,557,323$ \\
\hline $\mathrm{N}$ & $\mathrm{H}$ & $\mathrm{V}_{0}(\mathrm{~N} \mid \mathrm{H})$ & $\mathrm{x}$ & $\mathrm{x}$ & $\mathrm{x}$ & $\mathrm{x}$ & $x_{2}$ & $\mathrm{x}$ & $18,476,259$ & $5,833,337$ \\
\hline $\mathrm{H}$ & $\mathrm{N}$ & $\mathrm{V}_{0}(\mathrm{H} \mid \mathrm{N})$ & $\mathrm{x}$ & $\mathrm{X}$ & $\mathrm{x}$ & $\mathrm{X}$ & $x y$ & $\mathrm{x}$ & $19,901,251$ & $20,479,457$ \\
\hline \multirow[t]{3}{*}{$\mathrm{H}$} & $\mathrm{H}$ & $\mathrm{V}_{0}(\mathrm{H} \mid \mathrm{H})$ & $\mathrm{x}$ & & & $\mathrm{x}$ & & & $19,746,000$ & $7,139,969$ \\
\hline & & & & $\mathrm{x}$ & & & $\mathrm{x}$ & & $19,111,130$ & $6,486,653$ \\
\hline & & & & & $\mathrm{X}$ & & & $\mathrm{x}$ & $18,793,694$ & 6,159,995 \\
\hline $\mathrm{N}$ & $\mathrm{N}$ & $\mathrm{V}_{1}(\mathrm{~N} \mid \mathrm{N})$ & $\mathrm{x}$ & $\mathrm{x}$ & $\mathrm{x}$ & $\mathrm{X}$ & 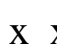 & $\mathrm{x}$ & $20,948,685$ & $21,557,323$ \\
\hline \multirow[t]{3}{*}{$\mathrm{N}$} & $\mathrm{H}$ & $\mathrm{V}_{1}(\mathrm{~N} \mid \mathrm{H})$ & & & & $\mathrm{x}$ & $\mathrm{x}$ & & $19,094,366$ & $9,764,334$ \\
\hline & & & & & & & & $\mathrm{x}$ & $18,723,502$ & $7,405,736$ \\
\hline & & & $\mathrm{X}$ & $\mathrm{X}$ & $\mathrm{X}$ & & & & $18,476,259$ & $5,833,337$ \\
\hline $\mathrm{H}$ & $\mathrm{N}$ & $\mathrm{V}_{1}(\mathrm{H} \mid \mathrm{N})$ & $\mathrm{x}$ & $\mathrm{x}$ & $\mathrm{x}$ & $\mathrm{X}$ & $\mathrm{X} \quad \mathrm{r}$ & $\mathrm{x}$ & $19,901,251$ & $20,479,457$ \\
\hline \multirow[t]{6}{*}{$\mathrm{H}$} & $\mathrm{H}$ & $\mathrm{V}_{1}(\mathrm{H} \mid \mathrm{H})$ & $\mathrm{x}$ & & & & & & $19,746,000$ & $7,139,969$ \\
\hline & & & & $\mathrm{x}$ & & & & & $19,111,130$ & $6,486,653$ \\
\hline & & & & & $\mathrm{X}$ & & & & $18,793,694$ & $6,159,995$ \\
\hline & & & & & & $X$ & & & $20,364,107$ & $11,070,965$ \\
\hline & & & & & & & $\mathrm{X}$ & & $19,729,236$ & $10,417,649$ \\
\hline & & & & & & & & $\mathrm{x}$ & $19,040,937$ & $7,732,394$ \\
\hline
\end{tabular}

Notes:

Values are in 2005 dollars.

For model specifications, see Table 3. 
Table 5. Likelihood Distributions: Prob(x|s)

\begin{tabular}{llrr}
\hline \multicolumn{2}{c}{ Accuracy of PredictionState s } & \multicolumn{2}{c}{ Forecast $\mathrm{x}$} \\
& & HAB & No HAB \\
\hline $100 \%$ & HAB & 1 & 0 \\
& No HAB & 0 & 1 \\
& & & \\
$90 \%$ & HAB & 0.9 & 0.1 \\
& No HAB & 0.1 & 0.9 \\
& & & \\
$80 \%$ & HAB & 0.8 & 0.2 \\
& No HAB & 0.2 & 0.8 \\
\hline
\end{tabular}


Table 6. Posterior Distributions: Prob(s|x)

\begin{tabular}{|c|c|c|c|c|}
\hline \multirow[t]{2}{*}{ HAB Frequency } & \multirow{2}{*}{$\begin{array}{l}\text { Accuracy of } \\
\text { Prediction }\end{array}$} & \multirow{2}{*}{$\begin{array}{l}\text { State of } \\
\text { Nature s }\end{array}$} & \multicolumn{2}{|c|}{ Forecast $\mathrm{x}$} \\
\hline & & & HAB & No HAB \\
\hline \multirow[t]{6}{*}{ 2-year event } & $100 \%$ & НАВ & 1.000 & 0.000 \\
\hline & & No HAB & 0.000 & 1.000 \\
\hline & $90 \%$ & HAB & 0.900 & 0.100 \\
\hline & & No HAB & 0.100 & 0.900 \\
\hline & $80 \%$ & HAB & 0.800 & 0.200 \\
\hline & & No HAB & 0.200 & 0.800 \\
\hline \multirow[t]{6}{*}{ 5-year event } & $100 \%$ & НAB & 1.000 & 0.000 \\
\hline & & No HAB & 0.000 & 1.000 \\
\hline & $90 \%$ & HAB & 0.692 & 0.027 \\
\hline & & No HAB & 0.308 & 0.973 \\
\hline & $80 \%$ & HAB & 0.500 & 0.059 \\
\hline & & No HAB & 0.500 & 0.941 \\
\hline \multirow[t]{6}{*}{ 10-year event } & $100 \%$ & HAB & 1.000 & 0.000 \\
\hline & & No HAB & 0.000 & 1.000 \\
\hline & $90 \%$ & HAB & 0.500 & 0.012 \\
\hline & & No HAB & 0.500 & 0.988 \\
\hline & $80 \%$ & HAB & 0.308 & 0.027 \\
\hline & & No HAB & 0.692 & 0.973 \\
\hline \multirow[t]{6}{*}{ 20-year event } & $100 \%$ & HAB & 1.000 & 0.000 \\
\hline & & No HAB & 0.000 & 1.000 \\
\hline & $90 \%$ & HAB & 0.321 & 0.006 \\
\hline & & No HAB & 0.679 & 0.994 \\
\hline & $80 \%$ & HAB & 0.174 & 0.013 \\
\hline & & No HAB & 0.826 & 0.987 \\
\hline \multirow[t]{6}{*}{ 30-year event } & $100 \%$ & НАВ & 1.000 & 0.000 \\
\hline & & No HAB & 0.000 & 1.000 \\
\hline & $90 \%$ & НАВ & 0.237 & 0.004 \\
\hline & & No HAB & 0.763 & 0.996 \\
\hline & $80 \%$ & НAB & 0.121 & 0.009 \\
\hline & & No HAB & 0.879 & 0.991 \\
\hline
\end{tabular}


Table 7. Annual Value of HAB Prediction due to Increased Harvest in March

\begin{tabular}{|c|c|c|c|c|c|}
\hline \multirow[t]{2}{*}{ HAB Frequency } & \multirow{2}{*}{$\begin{array}{l}\text { Accuracy of } \\
\text { Prediction }\end{array}$} & \multirow{2}{*}{ State } & \multicolumn{3}{|c|}{ Value } \\
\hline & & & Model A & Model B & Model C \\
\hline \multirow[t]{9}{*}{ 2-year event } & \multirow[t]{3}{*}{$100 \%$} & ME & 523,717 & 317,435 & 158,718 \\
\hline & & MA & 538,933 & 326,658 & 163,329 \\
\hline & & Total & $1,062,650$ & 644,093 & 322,047 \\
\hline & \multirow[t]{3}{*}{$90 \%$} & $\mathrm{ME}$ & 407,858 & 233,320 & 90,474 \\
\hline & & MA & 419,708 & 240,099 & 93,103 \\
\hline & & Total & 827,566 & 473,419 & 183,577 \\
\hline & \multirow[t]{3}{*}{$80 \%$} & ME & 292,000 & 149,205 & 22,231 \\
\hline & & MA & 300,483 & 153,540 & 22,877 \\
\hline & & Total & 592,483 & 302,745 & 45,108 \\
\hline \multirow[t]{9}{*}{ 5-year event } & \multirow[t]{3}{*}{$100 \%$} & ME & 253,948 & 126,974 & 63,487 \\
\hline & & MA & 261,326 & 130,663 & 65,332 \\
\hline & & Total & 515,274 & 257,637 & 128,819 \\
\hline & \multirow[t]{3}{*}{$90 \%$} & ME & 144,759 & 30,482 & 0 \\
\hline & & MA & 148,964 & 31,368 & 0 \\
\hline & & Total & 293,723 & 61,850 & 0 \\
\hline & \multirow[t]{3}{*}{$80 \%$} & ME & 35,569 & 0 & 0 \\
\hline & & MA & 36,603 & 0 & 0 \\
\hline & & Total & 72,172 & 0 & 0 \\
\hline \multirow[t]{9}{*}{ 10-year event } & \multirow[t]{3}{*}{$100 \%$} & ME & 126,974 & 63,487 & 31,744 \\
\hline & & MA & 130,663 & 65,332 & 32,666 \\
\hline & & Total & 257,637 & 128,819 & 64,410 \\
\hline & \multirow[t]{3}{*}{$90 \%$} & ME & 20,008 & 0 & 0 \\
\hline & & MA & 20,589 & 0 & 0 \\
\hline & & Total & 40,597 & 0 & 0 \\
\hline & \multirow[t]{3}{*}{$80 \%$} & $\mathrm{ME}$ & 0 & 0 & 0 \\
\hline & & MA & 0 & 0 & 0 \\
\hline & & Total & 0 & 0 & 0 \\
\hline \multirow[t]{9}{*}{ 20-year event } & \multirow[t]{3}{*}{$100 \%$} & ME & 63,487 & 31,744 & 15,872 \\
\hline & & MA & 65,332 & 32,666 & 16,333 \\
\hline & & Total & 128,819 & 64,410 & 32,205 \\
\hline & \multirow[t]{3}{*}{$90 \%$} & ME & 0 & 0 & 0 \\
\hline & & MA & 0 & 0 & 0 \\
\hline & & Total & 0 & 0 & 0 \\
\hline & \multirow[t]{3}{*}{$80 \%$} & $\mathrm{ME}$ & 0 & 0 & 0 \\
\hline & & MA & 0 & 0 & 0 \\
\hline & & Total & 0 & 0 & 0 \\
\hline \multirow[t]{9}{*}{ 30-year event } & \multirow[t]{3}{*}{$100 \%$} & ME & 42,325 & 21,162 & 10,581 \\
\hline & & MA & 43,554 & 21,777 & 10,889 \\
\hline & & Total & 85,879 & 42,939 & 21,470 \\
\hline & \multirow[t]{3}{*}{$90 \%$} & ME & 0 & 0 & 0 \\
\hline & & MA & 0 & 0 & 0 \\
\hline & & Total & 0 & 0 & 0 \\
\hline & $80 \%$ & $\mathrm{ME}$ & 0 & 0 & 0 \\
\hline & & MA & 0 & 0 & 0 \\
\hline & & Total & 0 & 0 & 0 \\
\hline
\end{tabular}

Note:

Values are in 2005 dollars.

For model specifications, see Table 3. 
Table 8. Annual Value of HAB Prediction due to Reduction in Closed Areas

\begin{tabular}{llrrrrr}
\hline $\begin{array}{l}\text { Increased Harvest } \\
\text { during HAB }\end{array}$ & State & \multicolumn{1}{c}{$\begin{array}{c}\text { 2-year } \\
\text { event }\end{array}$} & \multicolumn{1}{c}{$\begin{array}{c}\text { 5-year } \\
\text { event }\end{array}$} & $\begin{array}{c}\text { 10-year } \\
\text { event }\end{array}$ & \multicolumn{1}{c}{$\begin{array}{c}\text { 20-year } \\
\text { event }\end{array}$} & \multicolumn{1}{c}{$\begin{array}{c}\text { 30-year } \\
\text { event }\end{array}$} \\
\hline $10 \%$ & ME & 123,621 & 49,449 & 24,724 & 12,362 & 8,241 \\
& MA & 786,199 & 314,480 & 157,240 & 78,620 & 52,413 \\
& Total & 909,820 & 363,929 & 181,964 & 90,982 & 60,655 \\
& & & & & & \\
$25 \%$ & ME & 309,053 & 123,621 & 61,811 & 30,905 & 20,604 \\
& MA & $1,965,498$ & 786,199 & 393,100 & 196,550 & 131,033 \\
& Total & $2,274,551$ & 909,820 & 454,910 & 227,455 & 151,637 \\
\hline
\end{tabular}

Note: Values are in 2005 dollars. 
Table 9. Total Annual Value of HAB Prediction

\begin{tabular}{|c|c|c|c|c|c|}
\hline \multirow[t]{2}{*}{ HAB Frequency } & \multirow{2}{*}{$\begin{array}{l}\text { Accuracy of } \\
\text { Prediction }\end{array}$} & \multirow{2}{*}{ State } & \multicolumn{3}{|c|}{ Value } \\
\hline & & & Model D & Model E & Model F \\
\hline \multirow[t]{9}{*}{ 2-year event } & \multirow[t]{3}{*}{$100 \%$} & ME & 832,770 & 626,489 & 282,339 \\
\hline & & MA & $2,504,431$ & $2,292,156$ & 949,528 \\
\hline & & Total & $3,337,201$ & $2,918,645$ & $1,231,867$ \\
\hline & \multirow[t]{3}{*}{$90 \%$} & $\mathrm{ME}$ & 716,912 & 542,373 & 214,095 \\
\hline & & MA & $2,385,206$ & $2,205,597$ & 879,302 \\
\hline & & Total & $3,102,118$ & $2,747,970$ & $1,093,397$ \\
\hline & \multirow[t]{3}{*}{$80 \%$} & ME & 601,053 & 458,258 & 145,852 \\
\hline & & MA & $2,265,982$ & $2,119,038$ & 809,076 \\
\hline & & Total & $2,867,035$ & $2,577,296$ & 954,928 \\
\hline \multirow{9}{*}{ 5-year event } & \multirow{3}{*}{$100 \%$} & ME & 377,570 & 250,595 & 112,936 \\
\hline & & MA & $1,047,526$ & 916,862 & 379,811 \\
\hline & & Total & $1,425,096$ & $1,167,457$ & 492,747 \\
\hline & \multirow[t]{3}{*}{$90 \%$} & ME & 268,380 & 154,103 & 49,449 \\
\hline & & MA & 935,164 & 817,567 & 314,480 \\
\hline & & Total & $1,203,544$ & 971,670 & 363,929 \\
\hline & \multirow[t]{3}{*}{$80 \%$} & ME & 159,190 & 123,621 & 49,449 \\
\hline & & MA & 822,802 & 786,199 & 314,480 \\
\hline & & Total & 981,992 & 909,820 & 363,929 \\
\hline \multirow[t]{9}{*}{ 10-year event } & \multirow[t]{3}{*}{$100 \%$} & ME & 188,785 & 125,298 & 56,468 \\
\hline & & MA & 523,763 & 458,432 & 189,906 \\
\hline & & Total & 712,547 & 583,729 & 246,374 \\
\hline & \multirow[t]{3}{*}{$90 \%$} & ME & 81,819 & 61,811 & 24,724 \\
\hline & & MA & 413,689 & 393,100 & 157,240 \\
\hline & & Total & 495,507 & 454,911 & 181,964 \\
\hline & \multirow[t]{3}{*}{$80 \%$} & $\mathrm{ME}$ & 61,811 & 61,811 & 24,724 \\
\hline & & MA & 393,100 & 393,100 & 157,240 \\
\hline & & Total & 454,911 & 454,911 & 181,964 \\
\hline \multirow[t]{9}{*}{ 20-year event } & \multirow[t]{3}{*}{$100 \%$} & ME & 94,392 & 62,649 & 28,234 \\
\hline & & MA & 261,882 & 229,216 & 94,953 \\
\hline & & Total & 356,274 & 291,865 & 123,187 \\
\hline & \multirow[t]{3}{*}{$90 \%$} & ME & 30,905 & 30,905 & 12,362 \\
\hline & & MA & 196,550 & 196,550 & 78,620 \\
\hline & & Total & 227,455 & 227,455 & 90,982 \\
\hline & \multirow[t]{3}{*}{$80 \%$} & $\mathrm{ME}$ & 30,905 & 30,905 & 12,362 \\
\hline & & MA & 196,550 & 196,550 & 78,620 \\
\hline & & Total & 227,455 & 227,455 & 90,982 \\
\hline \multirow[t]{9}{*}{ 30-year event } & \multirow[t]{3}{*}{$100 \%$} & ME & 62,929 & 41,766 & 18,822 \\
\hline & & MA & 174,587 & 152,810 & 63,302 \\
\hline & & Total & 237,516 & 194,576 & 82,125 \\
\hline & \multirow[t]{3}{*}{$90 \%$} & ME & 20,604 & 20,604 & 8,241 \\
\hline & & MA & 131,033 & 131,033 & 52,413 \\
\hline & & Total & 151,637 & 151,637 & 60,654 \\
\hline & $80 \%$ & $\mathrm{ME}$ & 20,604 & 20,604 & 8,241 \\
\hline & & MA & 131,033 & 131,033 & 52,413 \\
\hline & & Total & 151,637 & 151,637 & 60,654 \\
\hline
\end{tabular}

Notes:

Values are in 2005 dollars.

For model specifications, see Table 3. 
Table 10. Net Present Value over 30 Years

\begin{tabular}{lccccc}
\hline HAB Frequency & 2-year event & 5-year event & 10-year event & 10-year event & 30-year event \\
Accuracy of & & & & & \\
Prediction & $100 \%$ & $80 \%$ & $100 \%$ & $100 \%$ & $90 \%$ \\
Model & $\mathrm{D}$ & $\mathrm{E}$ & $\mathrm{D}$ & $\mathrm{E}$ & $\mathrm{F}$ \\
Annual Value & & & & & \\
$(2005 \$)$ & $3,337,201$ & 909,820 & 712,547 & 583,729 & 60,654 \\
NPV $(2005 \$)$ & $51,300,959$ & $13,986,163$ & $10,953,598$ & $8,973,350$ & 932,401 \\
\hline
\end{tabular}

Note:

Interest rate $=5 \%$.

For model specifications, see Table 3. 
Figure 1. Value of Monthly Shellfish Landings in Maine: with vs. without HAB Forecast

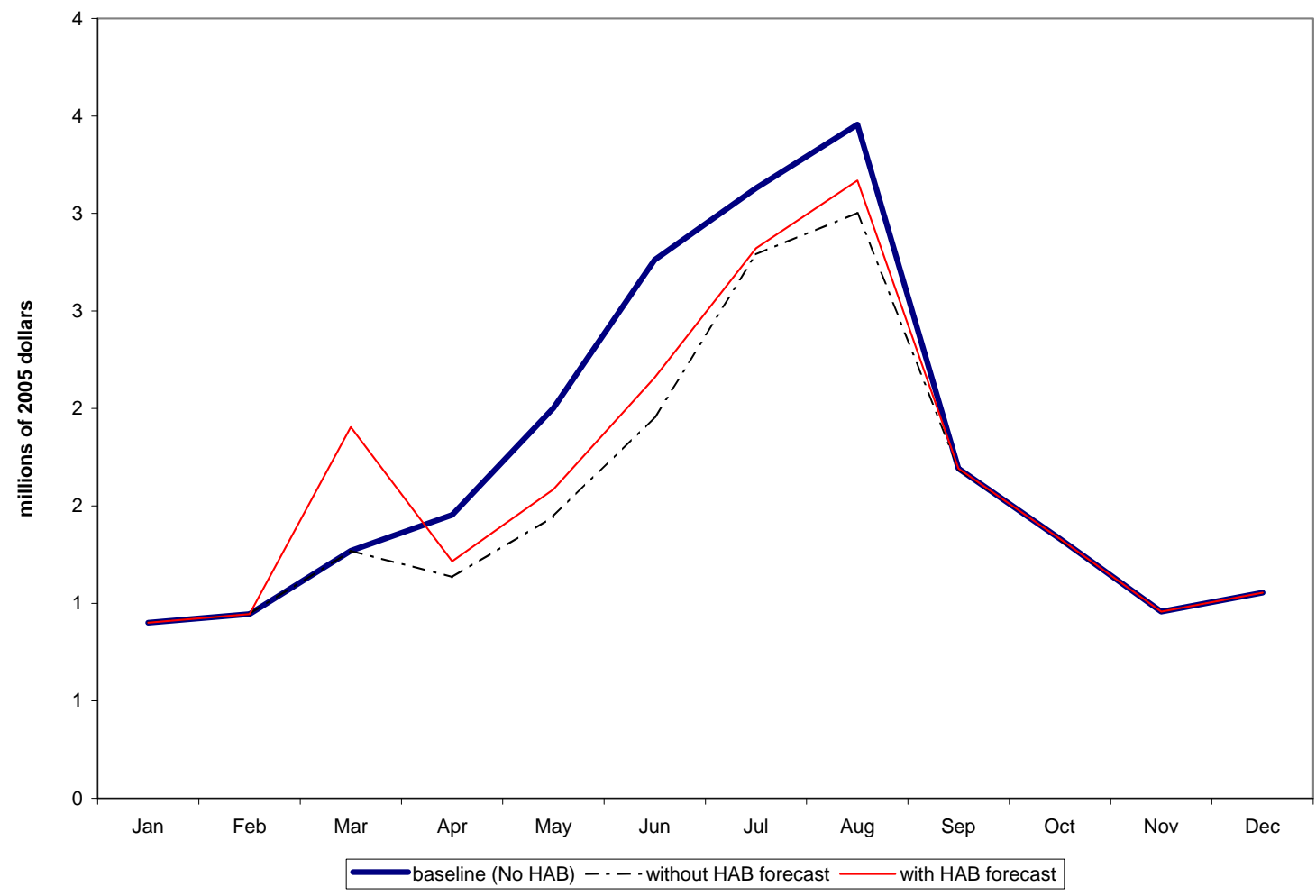

Note: With HAB predicted, landings grow 50\% from baseline level in March and losses decrease by 25\% during April through August. 